Volume 7 Issue 1, March 2020

Nationally Accredited Journal,

Decree No. B/4130/E5/E5.2.1/2019

\title{
Juridical Study With Deed Of Under Hand Evidence Which Notarized In Completion Case In Court
}

\author{
Eko Nurhanafi ${ }^{1}$, Akhmad Khisni ${ }^{2}$ and Amin Purnawan ${ }^{3}$
}

\begin{abstract}
This study aims to assess and analyze: 1 ). Notary form of responsibility for the validity of the deed under which legalized hand. 2). The strength of evidence by deed under the hand which has been legalized by the Notary in settling disputes in court. 3). The authority of the judge in dismissing deed under the hand that had to notarize a Notary.

Research using normative juridical, The collection of primary and secondary data obtained by interview and literature study, then analyzed by qualitative analysis method.

Based on the results of this study concluded that: 1). Notary form of responsibility for the validity of the deed under which legalized hand there is the certainty that the signature means certain that the signature was indeed the parties to the agreement and not others. It is said that because of legalizing the letter should be required to know the people who are signing an a way to see his ID such as Identity Card and others. 2). The strength of evidence by deed under the hand which has been legalized by the Notary in settling disputes in court that the evidence is perfect as an authentic deed. Deed under the hand that has obtained the legalization of Notaries has the strength of evidence was perfect, because the deed under the hand of the truth lies in the signatures of the parties. So with the recognition of such signatures, then the contents of the deed was regarded as an agreement between the parties. 3) The authority of judges to cancel the deed under the hand that had to notarize the notary is a judge can only do that if put to him a certificate as evidence. The judge on his own initiative may not make a decision without their deed as evidence written agreement.
\end{abstract}

Keywords: Notary; Strength of Evidence; Deeds Under Hand

\section{Introduction}

The position of a notary as funcionarity in society is considered as an official where a person can obtain advice that may be relied upon in making a strong and ratification documents in a legal process. Society needs a (figure) that its provisions are reliable, trustworthy, and the signature and seal (stamp) guarantees and compelling evidence, an expert advisory impartial and without blemish (onkreukbaar or unimpeachable), which shut up, and make a pact to protect it on the day that will come. ${ }^{4}$

Legal protection of the Notary in carrying out its duties and authorities for the implementation of service functions and the achievement of legal certainty in providing services to the public, has been regulated and set forth in the new legislation, Article 1 paragraph 1 of Act No. 2 of 2014 on the Amendment of the Act No. 30 of 2004 concerning Notary determine:

\footnotetext{
${ }^{1}$ Students of Master of Notary Program, Faculty of Law, Sultan Agung Islamic University (UNISSULA), Semarang, email: eko.nurhanafish@ymail.com

${ }^{2}$ Lecturer of Master of Notarial Law, Sultan Agung Islamic University (UNISSULA), Semarang

3 Lecturer of Master of Notarial Law, Sultan Agung Islamic University (UNISSULA), Semarang

${ }^{4}$ Tang Thong Kie, 2007, Studi Notariat \& Serba Serbi Praktek Notaris, New Ichtiar Van Hoave, Jakarta, p. 162.
} 
"Notary is a public official authorized to make an authentic deed and have more authority as referred to in this Act or under any other laws."

Authentic deed of Notary substantially in accordance with what was notified of the parties to the Notary. Notary is obliged to enter into a deed of what is wanted the parties and then pour statements or statements of the parties to the notary deed. While writing under the hand or commonly called the deed under the hand made is not made before a Notary and in a form that is not defined by law and without any intermediary pursuant to Article 1874 Book of the Civil Law.

Liability is determined by the nature of the offense and the legal consequences arising. In general, the usual accountability imposed on the Notary is the responsibility of criminal, administrative and civil. Accountability is criminally sanctioned criminal administrative responsibility administrative sanctions and civil liability civil sanctions. It is a consequence of the breach of or omissions by the Notary in the process of making an authentic deed.

Determining the existence of a civil or criminal liability is performed by a Notary three conditions must be met, ie there must be a Notary deed punishable whose elements are strictly defined by law. The Notary acts contrary to the law, and must be a mistake of the Notary Public. Errors or omissions in the criminal sense includes elements contrary to the law and there should be a tort. So basically any form of violation or omissions Notary necessarily contain unlawfully in the nature of the act.

If a deed, birth rights and obligations of the parties shall meet then a matter of what was agreed and the other party is entitled to demand. Notary simply maker for the birth of an authentic deed. Besides, the notary is authorized also to certify the lye hands and establish certainty the date of the letter under the hand by listing them in a book that is special or called legalization, but in reality among the general public there is still confusion about the meaning and function of the legalization of the deed under the hand by a Notary.

In connection with the above background, it is encouraging writers to conduct research and poured in the form of a thesis entitled "Study of the Deed Under Juridical Proof Hand notarized in the Settlement of the Case in Court"

This study sought to answer concerns regarding forms of Notary responsibility for the validity of the deed under which legalized hand, the strength of evidence by deed under the hand which has been legalized by the Notary in settling disputes in court, as well as the authority of the judge in dismissing deed under the hand that had to notarize a Notary.

\section{Research methods}

The method used in this research is normative juridical approach. Specification The research was analytic descriptive describes the applicable laws and regulations associated with the law theories and practice implementation. ${ }^{5}$ Primary and secondary data sources obtained by interview and review of the literature (document study). The data have been collected either from field research and literature research will be analyzed with descriptive analysis method and qualitative analysis.

\footnotetext{
${ }^{5}$ Sumardi Suryabrata, 1993, Metodologi Penelitian, Rajawali, Jakarta, p.19
} 
Volume 7 Issue 1, March 2020

Nationally Accredited Journal,

Decree No. B/4130/E5/E5.2.1/2019

\section{Results and Discussion}

\subsection{The Responsibility of Notary on the Truth of Deed Evidence Under His Legalization}

Legalization of a deed by the Notary is an effort so that the engagement of the binding legal force for sure, because by doing an engagement by a Notary legalization, it will make it into a deed of authentic engagement for parties bound. Then in Article 15 (1) and (2) of Act No. 2 of 2014 on the Amendment of Act No. 30 of 2004 concerning Notary Regulation also determined that:

- Notary authorized to make the deed authentic of all deeds, agreements and statutes that are required by legislation and / or desired by the stakeholders to be stated in the certificate is authentic, guaranteeing the creation date of the deed, saving certificates, giving groose, copy, and official copies, or excluded to another official or other person specified by law.

- Notary authorities also:

- Certify the signatures and set a firm date under the letter of the hand by enrolling in a special book

- Letters posted under hand by enrolling in a special book

- Make copies of the original letters in the form of a copy under the hand that contains a description as written and illustrated in the letter in question.

- Approve their compatibility with a photocopy of the original letter

- Providing legal counseling in connection with a deed

- A deed relating to land

- Creating a treatise deed auction. ${ }^{6}$

Notary Deed made in accordance with the will of the parties concerned in order to ensure or guarantee the rights and obligations of the parties, certainty, order and legal protection of the parties. Notary deed containing essentially the truth according to what is notified by the parties to a public official. Notary has the obligation to enter into a deed of what is truly understood in accordance with the will of the parties and read it to the side so that it became clear the contents of the deed. Statements or statements of the parties by a Notary forth in the notarial deed. ${ }^{7}$

In connection with the issue of the responsibility of the Notary of the authentic act that results were made null and void, then the Notary responsible individual (individual) or a deed made personally against it. Notary as a public official may be requested for accountability for the authentic act that results null and void were made based on the sharing of responsibility which can overload a notary is a personal responsibility, that a notary is responsible for the offense itself. $^{8}$

As set forth in Article 15 paragraph 2 letter a of Law Notary (UUJN) No. 2 of 2014, Notary has one authority certify signatures and establishes the certainty of the date of the letter under the hand, the parties signed an agreement under hand before a Notary to Notaries can validate the signature and date of signing. That is, that Waarmerking is giving the exact date of which is a statement that the Notary actually see the existing deed and recorded in a special book (instead of the date the deed is signed under the hand). Waarmerking legal implications of the Notary is not great

\footnotetext{
${ }^{6}$ Article 15 of Act No. 2 of 2014 on the Rules of Notary

${ }^{7}$ Habib Adjie, op.cit, p. 121.

${ }^{8}$ Ibid
} 
because of the Notary only record the exact date of the Notary deed under the hand saw. ${ }^{9}$

This is in contrast with legalization, although the notary did not join a deed under hand, but has a pretty big responsibility because in the legalization of the notary must know the person who signed his name before a Notary. The letter under the hand against legalized by the Notary, the Notary is responsible for four things:

- Identity

- Notary is obliged to investigate the identity of the parties will sign a letter / certificate under the hand (ID card, passport, driving license), or known by others.

- Examine whether competent to perform legal acts

- Examining whether authorized parties signed a letter / certificate

- The contents of the Deed

Notary deed shall read out to the parties and ask you if it so desired contents the deed of third parties.

- They must sign a signature before Notary

- Date, which affix the date on the deed under the hand and then posted to the register which has been provided to it. ${ }^{10}$

In Waarmerking deed under the hand, according to the notary responsibility UUJN No. 2 of 2014 are not so apparent, since the date, signature, the letter is not known to the notary. Notary of the letter under the hand only to admit that on this day has come at the office of a notary, are numbered, entered into a register Waarmerking and given written by a notary that the letter numbered and entered into a register that is specifically made for it, given stamp duty, signed by a Notary and then returned to the person concerned. Before being returned each page is numbered and initialed by the notary. ${ }^{11}$

The above can be said, that the responsibility for the correctness Notary deed under hand legalized is certainty signature means certain that the signature was indeed the parties to the agreement and not others. It is said that because of legalizing the letter should be required to know the people who are signing an a way to see his ID such as Identity Card and others.

Notaries can also read / explain the contents of the letter or simply validate the signature and date only certainty. The point remains on the parties must affix his signature before the Notary, then the signature authenticated by it. Notary set a firm date, as the date of signing of the agreement under the hands of the parties. Notary then writes the editorial legalization on the letter.

\subsection{Power Under the Deed of proof with hands notarized in the Settlement of the Case in Court}

According to Article 1866 of the Civil Code, verification tools include written evidence, witness evidence, conjecture, confession, and oath. Written evidence in question can be written in the form of authentic deed or deed under hand. In deed under the hand either in waarmeking or that legalization can be used as evidence in the trial but its strength is not the same. The legal force of legalizing more powerful than the waarmeking because by using means legalization of the signature is automatically performed before a Notary. So in this case Notaries may provide testimony as

\footnotetext{
${ }^{9}$ Interview with Irfina Rosalia, Notary in Temanggung, dated January 3, 2020

${ }^{10}$ Ibid

${ }^{11}$ Interview with Bambang Wahyudi, a Notary in Temanggung, dated January 3, 2020
} 
necessary to ensure the parties who signed the agreement and ensure the date of its signature in accordance with that implicit in Article 1874 of the Civil Code and Article 1874a. To waarmeking that can be ascertained only on the date of registration of the deed of Notary office concerned. For legalization in evidence during the trial of Notary has a role in recognizing or not and justify or not the owner of the signature deed.

Instead authentic deed is a deed made by or advance a public servant, by whom the deed was recorded in the statement it had sent a deed. Public servants in question here is that certain officials stated by law have the authority to make an authentic deed, for example sub-district head or a notary public, an authentic deed is no denying the truth unless it can be proven otherwise, for example no duplicity in the authentic deed. So for the judge would be very easy and does not hesitate in favor of plaintiffs who have been supported by evidence of an authentic deed. ${ }^{12}$

In contrast to the evidence in the form of a deed under the hand that only has a formal evidentiary force, ie when the signature on the legal deed (and this is already a proof of recognition), which means the statements contained in the certificate is recognized and justified anyway.

But materially, the strength of evidence deed under the hand only applies to the person to whom the statement was made, while on the other hand, the strength of the proof depends on the judge's assessment (probe free). All cases in the trial are solely included power or authority of a judge or court to decide. A judge or court of tools and equipment in a state of law that is assigned establishes the actual legal relationship between the two parties involved in a dispute.

In the trial, when offered as proof just a certificate under the hand given proof strength is limited, so they sought other evidence to support it in order to obtain evidence which was considered sufficient to reach the truth according to the law. ${ }^{13}$

So the deed under the hand can only be accepted as the beginning of written evidence (Article 1871 of the Civil Code), but according to that article does not explain what is meant by the documentary evidence. Article 1902 of the Civil Code in the proposed terms of the beginning when there is written evidence, namely: ${ }^{14}$

- There must be a deed

- It shall be made by the person against who made demands or of the person he represents

- It shall have to allow the truth of the events in question

So a deed under the hand to become perfect and complete evidence from the beginning of written evidence that they must be equipped with the tools of other evidence. Therefore it is said that the deed under the hand that is written evidence (Begin Van Schrifielijk Bewijs). ${ }^{15}$

Deed under the hand that has obtained the legalization give assurance to the judge about the date and the identity of the parties to the agreement and signature affixed under the letter did come from and affixed by a person whose name stated in the letter and the person who signed hands under the letter was no longer able to say that the parties, or one of the parties does not know what the contents of the letter, because its

\footnotetext{
${ }^{12}$ Interview with Isnaya Dewi, The Judge of Temanggung Court, dated January 3, 2020

${ }^{13}$ Ibid

${ }^{14} \mathrm{R}$. Soegondo Notodisoerjo, 2003, Hukum Notarial di Indonesia, Rajawali, Jakarta, p. 44.

${ }^{15}$ Meitinah, Pembuktian Kekuatan Di Bawah Tangan, Journal of Law and Development Year $36^{\text {th }}$ No.4 of 2016, p. 463
} 
contents have been read and explained prior to each side signed before the Notary Public. ${ }^{16}$

So the difference deed under the hand that was authorized by the competent authority for that and deed under the hand that is not legalized is that the letter under the hand that was authorized to have the exact date of signatures affixed under the letter did come and affixed by a person whose name noted in the letter and the person who signed his name under the letter was no longer able to say that he did not know what the letter said, because it was first read to him, before he signed his name in the presence of officials.

The strength of evidence material deed under the hand, according to Article 1875 of the Civil Code, by the people against the deed was used or that may be considered recognized by the laws of the signatory heirs as well as those who got the rights of the person, is a testament to perfect as an authentic deed.

Based on this, the deed under the hand that has obtained the legalization of Notaries has the strength of evidence was perfect, because the deed under the hand of the truth lies in the signatures of the parties. So with the recognition of such signatures, then the contents of the deed was regarded as an agreement between the parties.

\subsection{Judge Authority Which Can Canceling the Under Hand Deed Has Earned Legalization By Notaries}

In connection with the authority of the judge in deciding the cancellation of a certificate (either in the form of void or in the form of irrevocable), the judge can only do so when put to him a certificate as evidence. The judge on his own initiative may not make a decision without their deed as evidence written agreement. Decisionmaking of a judge is certainly depend on circumstances that serve as proof of the deed. Not all certificates are regarded one of the judges should be declared null and void. Even some fairly stated that the deed does not have the force of law. The verdict states that a notary deed not legally be taken if the notarial deed does not contain any errors which is the deed contents.

Fill the void deed, the deed itself is not canceled. This occurs if the certificate contains no legally flawed. Canceling only a legal action / legal events mentioned in the deed. If events occur should the court stated:

- Legal actions / events of the said law canceled / void (whichever is appropriate according to the case).

- Stating deed in question does not have the force / power valid as evidence.

Deed under the hand that has obtained the legalization of Notaries may be canceled by the judge if requested nullification though assignment judge in terms of proof only divide the burden of proof, but ex officio judge can not cancel a deed if not requested cancellation because the judge can not decide unsolicited. ${ }^{17}$

In terms of the deed under the hand that has obtained the legalization of Notary requested the cancellation, then the judge may cancel the certificate if there is evidence of an opponent. In general, the agreement is not tied to any particular form, but for some agreements, laws specify a particular shape so that when the form was not fulfilled, the agreement was not valid. For the validity of the agreement required four conditions:

- They agreed that bind

\footnotetext{
${ }^{16}$ Interview with Isnaya Dewi, The Judge of Temanggung Court, dated January 3, 2020

${ }^{17}$ Mertokusumo. Op.cit, p. 149.
} 
Volume 7 Issue 1, March 2020

Nationally Accredited Journal,

Decree No. B/4130/E5/E5.2.1/2019

- Competent to make an engagement

- A certain thing

- A cause that kosher

The first two conditions are subjective terms of an agreement. If this subjective requirement is not met, then the certificate can be canceled. While the latter two conditions objective requirements, because the object of the agreement and a deed may be null and void if the objective conditions of an agreement are not met.

\section{Closing}

\subsection{Conclusion}

- Notary form of responsibility for the validity of the deed under which legalized hand there is the certainty that the signature means certain that the signature was indeed the parties to the agreement and not others. It is said that because of legalizing the letter should be required to know the person signing an is a way to see his ID such as Identity Card and others, while at Waarmerking deed under hand, the responsibilities of a notary by UUJN No. 2 of 2014 are not so visible, because both dates, signature, the letter is not known to the notary. Notary of the letter under the hand is simply recognizing that today has come a notary office, given a number,

- The strength of evidence by deed under the hand which has been legalized by the Notary in settling disputes in court that deed under the hand that has obtained the legalization of Notaries has the strength of evidence was perfect, because the deed under the hand of the truth lies in the signatures of the parties. So with the recognition of such signatures, then the contents of the deed was regarded as an agreement between the parties.

- The authority of the judge in dismissing deed under the hand that had to notarize the notary is a judge can only do that if put to him a certificate as evidence. The judge on his own initiative may not make a decision without their deed as evidence written agreement. Not all certificates are regarded one of the judges should be declared null and void

\subsection{Suggestion}

- For people who want to make an agreement underhand letter expected to be more careful and pay close attention to making the agreement letter.

- Required dissemination to the wider community for understanding and legalized by a notary functions among the community there are differences of opinion.

\section{References}

[1] Daeng Naja, 2012, Teknik Pembuatan Akta, Pustaka Yustisia, Yogyakarta

[2] Peter Mahmud Marzuki, 2010, Penelitian Hukum, Kencana Prenada Media

[3] Salim HS 2010, Perkembangan Teori Dalam IImu Hukum, Rajawali Press, Jakarta

[4] Salim HS, 2016 Teknik Pembuatan Akta Satu, PT. RajaGrafindo Persada,

[5] Shidarta, 2006, Moralitas Profesi Hukum Suatu Tawaran Kerangka Berpikir, Refika Aditama, Bandung

[6] Sjaifurrachman and Habib Adjie, 2011, Aspek Pertanggungjawaban Notaris Dalam Pembuatan Akta, Mandar Maju, Bandung 


\section{JURNAL AKTA}

eISSN : 2581-2114, pISSN: 2406-9426

[7] Soerjono Soekanto 2006, Pengantar Penelitian Hukum, Molds 3rd, UI Press, Jakarta

[8] Subekti 2005, Hukum Pembuktian, PT. Pradnya Paramitha, Jakarta

[9] Supriya 2010, Etika dan Tanggung Jawab Profesi Hukum di Indonesia, Sinar Grafika, Jakarta

[10] Sutan Remy Sjahdeini 2009, Kebebasan Berkontrak dan Perlindungan Yang Seimbang Bagi Para Pihak Dalam Perjanjian di Indonesia, PT. Graffiti Pustaka Utama, Jakarta

[11] Act No. 2 of 2014 on the Amendment of Act No. 30 of 2004 concerning Notary.

[12] Emyuzar, 2017 Responsibility Against Notary Deed Under Hand formalized at the Notary Office, Journal of Legal Studies Program, Faculty of Law, University of Tamansiswa Padang

[13] Meitinah, Strength of Evidence Deed Under Hands, Journal of Law and Development Year $36^{\text {th }}$ No.4 of 2016 